\title{
Factors Affecting Fungicide Efficacy in the Tropics
}

\author{
Ricardo Balardin, Marcelo Madalosso, \\ Mônica Debortoli and Giuvan Lenz \\ Federal University of Santa Maria, \\ Brazil
}

\section{Introduction}

Fungicide efficacy at tropical conditions is influenced by pathogen population dynamics, abundant vegetative growth of the crops, several pathogen species attacking the whole cycle of the plant. Factors affecting fungicide efficacy can be summarized as the amount of fungicide that reach the plant tissue into a dense canopy, cultural management of the crop, dynamics of pathogen and plant population, and alternative or intermediate hosts management. The result of the fungicide spray is measured by absolute or relative residual. Most agriculturally important crops are sprayed with fungicides from 2 to 10 times every season. Such volume suggests negative impacts on the environment, difficult sustainability of the farmer, costly production system and need for continuous development of the fungicide technology. The most prominent characteristic of any fungicide is the efficacy that is closely related with the residual period along with the range of pathogens controlled. The residual of a fungicide depends on the chemical characteristic of each chemical group. The period of fullest fungicide activity is the absolute residual, while the effective residual will vary according to the interaction among fungicide intrinsic characteristics, stage of the pathogenesis and general physiological conditions of the plant at the moment of the spray. The tropical environment is optimum for fully fungal development providing stunting pathogenic activity during the whole cycle of a single crop. The synergistic effect showed by some fungicide mix shows longer relative residual than the observed when the fungicides are sprayed alone. In the absence of synergisms the residual observed will depends on the target mostly controlled. The mix of different fungicides is an alternative to avoid resistance risk along with pushing the control do higher efficacy levels.

\section{Timing of spray: preventative $x$ curative}

The chemical control success depends on the disease pathogenesis stageat any moment when the fungicide is applied. The fungicide application prior any contact between pathogen and host is considered to be preventative. After inoculation and just before initial symptoms, the application is curative. All applications made after the onset of symptoms is eradicative (Figure 1).The preventative spray protects host leaf area from pathogen invasion, providing greater control period and maximizing the residual period. As the infection takes 
place and the fungi develop into the plant tissue, the fungicide shows lower efficiency and the residual period decrease (Figure 2).

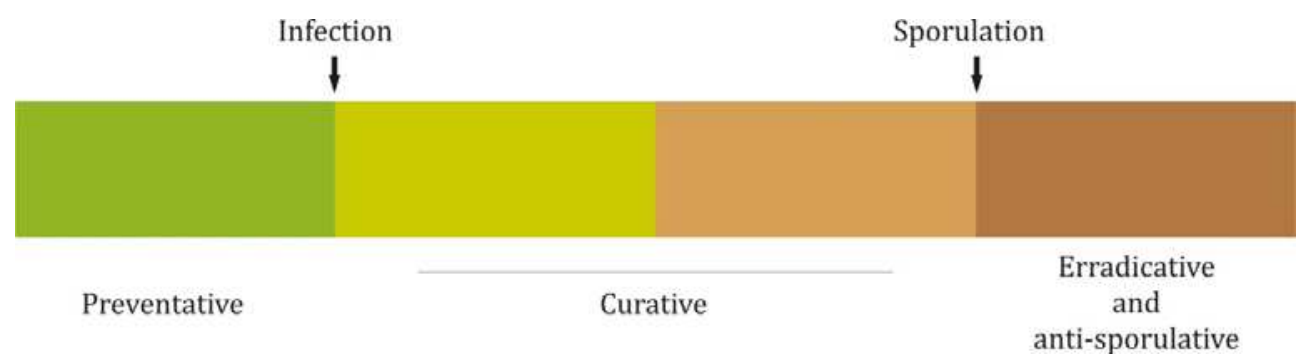

Fig. 1. Timing of fungicide application according to the host-pathogen interaction stages.

\section{$\square$ Erradicative $\times$ Curative $\diamond$ Preventive}

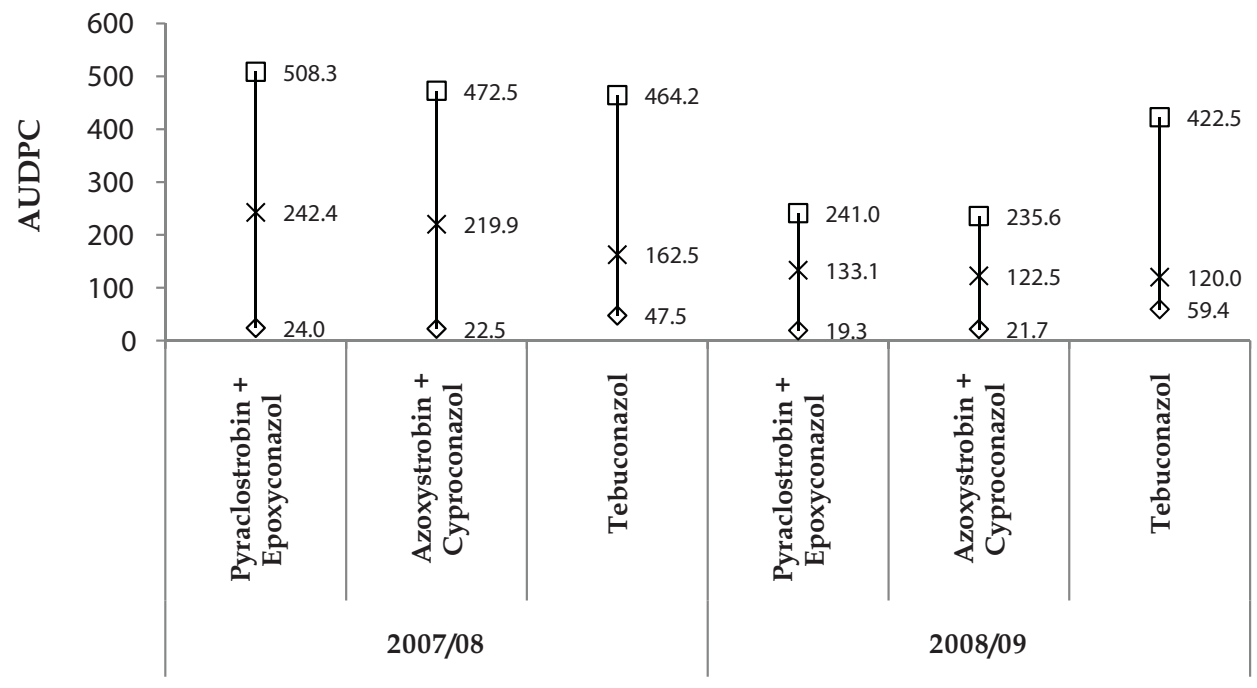

Fig. 2. Area Under Disease Progress Curve (AUDPC) determined for soybean rust after preventative application (14 days before inoculation), curative (3 days after inoculation) and eradicative ( 9 days after inoculation) of triazole + strobilurin and triazole fungicides.

After disease detection any delay on fungicide application will generate damage and efficacy reduction. Fungicide sprayed to control Soybean Asian Rust(SAR) seven days after first symptoms detection increased the defoliation up to $82 \%$. When the application was 14 days later the defoliation increased by $155 \%$ (Andrade \& Andrade, 2002).

Fungicide application made at the third day after inoculation(curative timing) reduced SAR severity and the disease progress of the rust, but with compromised efficiency. Higher curative / eradicative effect is observed at 48-72 hours after inoculation (Azevedo, 2001). 
Larger differences among active ingredients are also observed at the early stages of the infection. Such difference might be related to the early inhibition efficiency of leaf tissues, or even due to the fungistatic effect.

According to Ugalde (2005) the preventative control gives greater period of effective residual when Phakopsora pachyrhizi was inoculated two hours after fungicide spray. Similar results were observed even for inoculations performed at 10 and 14 days after fungicide spray. The period of effective residual of strobys + triazoles varies from 36 to 42 days after application at preventative sprays, reducing to 15 days when the application was done curatively.

The triazole + strobilurin mixture showed greater efficacy and longer residual in preventative applications comparing to the efficacy observed when the single active ingredients were sprayed separately(Andrade \& Andrade, 2002;Soares et al.,2004;Ugalde, 2005,Balardin, 2005).

\section{Fungicide application: spray technology}

The optimum residual period of a fungicide will varies according to host physiological characteristics, pathogen life cycle, and environmental characteristics. However, the correct placement of the fungicide droplet on the leaf tissue will also be decisive.

The establishment of pathogenesis requires a film of water for spore germination, conditions usually observed at the lower portion of the canopy. However, at this part of the plant coverage and penetration by the fungicide tend to be more difficult to achieve. Directly, when the product is placed at the target, and indirectly when the redistribution process takes place systemically.

Studies on droplet size for a particular operation are helpful for better control. This choice depends on weather conditions, leaf area index and plant architecture. A better choice of a spectrum of spraying is related to characteristics of the drops, which are important for canopy penetration and coverage. The spectrum of the spray is characterized by parameters such as volume median diameter (VMD), number median diameter (NMD) and relative amplitude (RA) that allow expressing the numerical size and uniformity of drops.

The VMD is the value expressed in micrometers $(\mathrm{mm})$, which represents the droplet diameter that divides the total into two equal halves, i.e. half the volume consists of sprayed droplets smaller than the VMD and the other half in drops larger than this value. Note that the value VMD is located closer to the upper range of diameter classes, because the volume of a few big drops is equivalent to that of many small droplets.

The NMD is the value also expressed in micrometers $(\mathrm{mm})$ and corresponds to the drop diameter, which divides the total number of droplets in two equal portions, where half the number of drops in the series is larger than the NMD and the other half of the droplets are smaller. Thus, the value of the NMD will necessarily be less than or equal to the NMD because the measure is independent of volume and the small droplets are considered in the same way that large.

Factors influencing the production of a particular droplet spectrum are: nominal flow rate, spray angle, pressure of the liquid properties of the syrup and type of spray tip. A particular point does not produce all the drops of the same size but a size range of droplets. In a spray with droplets of similar size spectrum is considered homogeneous, since with different sizes of droplets produced it is called heterogeneous (Christofoletti, 1999).

Under favorable environmental conditions (temperature $<30^{\circ} \mathrm{C}$ and relative humidity $>60 \%$ ) drops of thin spectrum maximize the penetration and coverage in all parts of the plant, 
especially to the bottom part of the canopy (Table 1). However, it should be noted that due to the small size of these droplets, there is a risk of drift due to wind speed above recommended. In the case of large drops, they usually deposit the drops on the upper surfaces and drip of the solution to the soil.

The application with coarse droplet spectrum can be an alternative for applications that target size is small and therefore does not require fine droplets to reach them. Likewise, in regions where the conditions of application are not appropriate due to the high potential risk of drift, the heterogeneous spectrum of drops has good performance, however, must take into account that this type of application provides less coverage of the target.

\begin{tabular}{|c|c|c|c|}
\hline Spray class & \multirow{2}{*}{ Symbol } & Color Code & VMD \\
\cline { 4 - 4 } & & ASAE $(\mu \mathrm{m})$ \\
\hline Very Fine & F & Red & $<100$ \\
\hline Fine & M & Yellow & $100-175$ \\
\hline Medium & C & Blue & $\mathbf{1 7 5}-250$ \\
\hline Large & VC & Green & $375-450$ \\
\hline Very Large & XC & White & $>450$ \\
\hline Extremely Large &
\end{tabular}

Table 1. Droplet size according to the classification from ASAE S-572.

Coverage is considered the number of drops per unit area (or percentage of covered area), obtained from the spray and the final result of spraying.

The ideal coverage should consider:

- The target to be controlled: diseases are mostly undercover requiring larger area of contact between product and plant. Also, initial infections are mostly established at lower parts of the plant canopy where the number of droplets is reduced. So, after disease established the chance of survival in oculum is as higher as fungicide is sprayed later.

- Fungicide mobility: it varies from none to full mobility into the plant tissue (contact or systemic).Contact fungicides require a direct deposition of the droplet on the target, so there is a need for a large number of droplets $/ \mathrm{cm}^{2}$.Systemic fungicides are absorbed by the leaves and redistributed through the xylem. However, because of the negative balance between mobility and residual period is necessary large number of droplets $/ \mathrm{cm}^{2}$.

The Coverage index $(C)$ is given by the formula $C=15$.V.R.K²/A.D, so $C=$ coverage $(\%$ of area), $\mathrm{V}=$ volume of spray $\left(\mathrm{L} \cdot \mathrm{ha}^{-1}\right), \mathrm{R}=$ recuperation tax, $\mathrm{K}=$ droplets spread, $\mathrm{A}=$ surface plant exists in hectare, and D = droplet diameter (Courshee, 1967 quoted by MATUO et al., 2005).

According to the parameters adopted by the $C$ index, to increase coverage just raises the volume of application $(\mathrm{V})$. The recovery rate $(\mathrm{R})$, corresponding to the percentage of applied volume captured by the target is dependent on several factors inherent to the technology of application and timing of application, droplet size and arrangement of plants appropriate. The droplets spread $(\mathrm{K})$ is a quadratic function that can be maximized by adding surfactants to the spray reducing the surface tension of the drop by reducing the angle of contact with the leaf surface.

Besides providing a larger area covered by drop, the reduction in surface tension allows the product to penetrate local and otherwise unable epidermis with dense trichomes. Regarding the denominator, the ratio is mathematically reverse, i.e., coverage will be difficult with the increase of leaf area per hectare, if maintaining the other conditions. 
Penetration is the ability to transpose dense layers of foliage, reaching the points of infection or healthy tissue inside the canopy. In general, small droplets penetrate easier the dense canopy of leaves.

During the crop cycle the leaf area index (LAI) increases. Adjustments must be made in the other parameters of the $\mathrm{C}$ index formula; otherwise the effectiveness of the application is greatly affected. Balardin (2005) observed better disease control at the end of the cycle with an increase in application volume as it increases the index leaf. Along with adjusting the volume of application (V), the change in drop size (D) and the addition of adjuvants to the spray solution benefiting the droplets spread (K) are possible strategies to be adopted.

Another way that expresses the target coverage is the droplets. $\mathrm{cm}^{-2}$. This parameter is more easily determined either in the form of manual counting or through specific software. It establishes the minimum number of droplets to allow minimum efficacy level of the fungicide. However, this measure varies widely depending on product characteristics and the addition of adjuvants, finding many discrepancies between researchers.

In the specific case of fungicides, Ozeki \& Kunz (1998) suggest a minimum of 30-50 droplets. $\mathrm{cm}^{-2}$ (systemic) and over 70 (contact). Christofoletti (1999) indicates the need of 3040 gotas. $\mathrm{cm}^{-2}$ (systemic) and between 50-70 (contact). Ugalde (2005) worked with application rates of 120 and 160 L.ha $^{-1}$ and showed a minimum coverage for systemic fungicide of 45 and 60 droplets.cm-2, respectively. Madalosso (2007) observed proportionality between increased row spacing and the coverage and penetration of droplets with greater fungicide efficacy (Table 2).

\begin{tabular}{|c|c|c|c|c|c|}
\hline \multicolumn{2}{|c|}{ Treatments } & \multirow{2}{*}{\multicolumn{2}{|c|}{$\frac{\mathrm{N}^{\circ} / \mathrm{cm}^{2}(2)}{\text { Average }}$}} & \multirow{2}{*}{\multicolumn{2}{|c|}{$\begin{array}{c}\text { AUDPC(3) } \\
\text { Average }\end{array}$}} \\
\hline \multirow{2}{*}{$\frac{\text { Rowspacing }(\mathrm{cm})}{30}$} & \multirow[t]{2}{*}{ Nozzle $^{(1)}$} & & & & \\
\hline & & $13^{(4)}$ & $\mathrm{a}$ & 101.33 & $\mathrm{C}$ \\
\hline 45 & \multirow[t]{2}{*}{ XR 11001} & 17 & $\mathrm{~b}$ & 88.89 & B \\
\hline 60 & & 56 & $\mathrm{C}$ & 71.56 & $\mathrm{~A}$ \\
\hline \multicolumn{2}{|c|}{ CV (\%) } & \multicolumn{2}{|c|}{8.48} & \multicolumn{2}{|c|}{11.53} \\
\hline 30 & \multirow{3}{*}{ TJ-60 11002} & 21 & $\mathrm{a}$ & 85.33 & $\mathrm{C}$ \\
\hline 45 & & 24 & $\mathrm{a}$ & 62.22 & B \\
\hline 60 & & 64 & $\mathrm{~b}$ & 53.56 & A \\
\hline \multicolumn{2}{|c|}{ CV (\%) } & \multicolumn{2}{|c|}{5.26} & \multicolumn{2}{|c|}{7.35} \\
\hline 30 & \multirow{3}{*}{ TXA 8002} & 25 & $\mathrm{a}$ & 89.78 & B \\
\hline 45 & & 26 & $\mathrm{a}$ & 65.56 & A \\
\hline 60 & & 53 & $\mathrm{~b}$ & 61.89 & A \\
\hline \multicolumn{2}{|c|}{ CV (\%) } & \multicolumn{2}{|c|}{7.62} & \multicolumn{2}{|c|}{9.64} \\
\hline 30 & \multirow{3}{*}{ Duo $(\mathrm{XR}+\mathrm{TT})$} & 5 & $\mathrm{a}$ & 119.56 & $\mathrm{C}$ \\
\hline 45 & & 13 & $\mathrm{~b}$ & 80.00 & B \\
\hline 60 & & 19 & c & 65.56 & A \\
\hline \multicolumn{2}{|c|}{ CV (\%) } & \multicolumn{2}{|c|}{8.74} & \multicolumn{2}{|c|}{13.63} \\
\hline
\end{tabular}

(1)Nozzles: XR 11001 (172 kPa), TJ-60 11002 (206 kPa), TXA 8002 (241 kPa)e o Turbo TeeJet® Duo - TT $11002+$ XR $11002(206 \mathrm{kPa})$ to 200 L.ha $^{-1}$. (2)Fungicide foliar coverage (number of drops.cm ${ }^{-2} .{ }^{(3)}$ Area Under Disease Progress Curve. ${ }^{(4)}$ Means followed by the same letter, within the variable number of drops.cm ${ }^{-2}$ and AUDPC for each spray tip, do not differ by Tukey test $(\mathrm{P} \leq 0,05)$.

Table 2. Coverage of droplets generated by spray nozzles at spaced 30, 45 and $60 \mathrm{~cm}$ between rows and Area Under Disease Progress Curve (Phakopsorapachyrhizi).Santa Maria, 2007. 
The biological efficacy of the fungicide depends on the quality of coverage and penetration as well as reducing losses through evaporation and drift, induced by droplet diameter. The increase in droplet diameter reduces drag drift by presenting fewer problems with evaporation on the path from the tip to the target, but promotes a lower coverage of the surface being treated.

\section{Fungicide application: cultural practices and plant physiology}

Soybean cultivars present different physiological characteristics. Cultural management equally extended to all varieties has reduced the crop yield potential, sometimes by a deficiency of the capture of solar radiation by poor distribution of plants in the area, sometimes by residual decline in disease control because of inadequate disposal of product or even both. Uneven distribution of yield components in the canopy generates a concentration of energy drag in the middle and upper part of the canopy. The bottom part of the canopy presents lower physiological influence on the final yield serving as substrate for infection and spread of pathogens. The environmental conditions observed in the bottom part of the canopy of the plants where the temperature undergoes minor changes and the dew has slowed its evaporation, determining a time of leaf wetness exceeding 8 hours per day are ideal for spore germination and infection (Balardin, 2005).These epidemiological parameters are achieved quickly with the density of plants in the area, either through higher densities, close spacing, or both. In this sense, this region of the plant has huge importance on chemical disease control. There are important points that can maximize the residual period of any fungicide application that go beyond the active ingredient, such as understanding the pathogenesis, correct application technology and physiological activity of the plant.

Several authors mention the fact that fast close space between lines result in increased incidence or severity of disease due to microclimate conditions formed within the canopy. Diseases like white mold (Sclerotiniasclerotiorum) (Elmore, 2004; Lee et al., 2003), anthracnose (Colletotrichumtruncatum) (EMBRAPA, 2006) and Asian Soybean Rust (Phakopsorapachyrhizi) (Madalosso et al., 2006) are examples of pathogens favored by higher plants density.

The most appropriate plant arrangement provide adverse epidemiological conditions slowing the rate of disease progress, due to greater distance between the lines, lower relative humidity, higher incidence of radiation, high temperature and consequently low leaf wetness.

The intensification of farming might facilitate the pathogen infection resulting in lower residual of the fungicide. The physical barrier imposed by the high rate of leaf area makes difficult the penetration and coverage of the fungicide on the leaves at the bottom part of the canopy. As a result, the amount of active ingredient can not reach the adequate quantity and quality to maintain the lethal effect on the pathogen (Table 3).

The number and size of droplets. $\mathrm{cm}^{-2}$ that reach the biological target determine the effectiveness of the fungicide application. Parameters such as penetration and coverage of the entire plant especially where the onset of the disease, are fundamental. Thus, the reduction in the spacing between lines increasing the number of leaves per $\mathrm{m}^{2}$, will reduce both the deposition of the fungicide and the residual control.

Several techniques are unsuccessful employed to maximize the deposition of the fungicide within the plant canopy. The alternative is to expose all the foliage of the plant to the fungicide through a better distribution of plants in the area, either by the greater spacing or by the lower plant density. 


\begin{tabular}{cccc}
\hline Row spacing $(\mathrm{cm})$ & Canopy portion & $\mathrm{N}^{\mathrm{o}} / \mathrm{cm}^{2}$ & Rate $^{*}$ \\
\hline \multirow{2}{*}{30} & Upper & 221 & 3.167 \\
& Medium & 15 & 0.214 \\
& Bottom & 11 & 0.157 \\
\hline \multirow{3}{*}{45} & Upper & 214 & 3.043 \\
& Medium & 20 & 0.286 \\
& Bottom & 13 & 0.186 \\
\hline \multirow{2}{*}{60} & Upper & 216 & 3.093 \\
& Medium & 57 & 0.814 \\
& Bottom & 43 & 0.614 \\
\hline
\end{tabular}

* 70 drops $/ \mathrm{cm}^{2}$

Table 3. Penetration and coverage of fungicide in thirds of the plant subjected to three different row spacing. Santa Maria / RS, 2007.

Larger distance between soybean rows maximizes the residual product, regardless of nozzles used, reducing the quantity and final establishment of disease (Figure 3).In this experiment, two fungicide applications were not enough to reduce the amount of disease at $30 \mathrm{~cm}$ space row, compared to 45 and $60 \mathrm{~cm}$. Fungicide sprayed on plants at $60 \mathrm{~cm}$ space row showed higher residual period along with longer green foliage and higher yield.

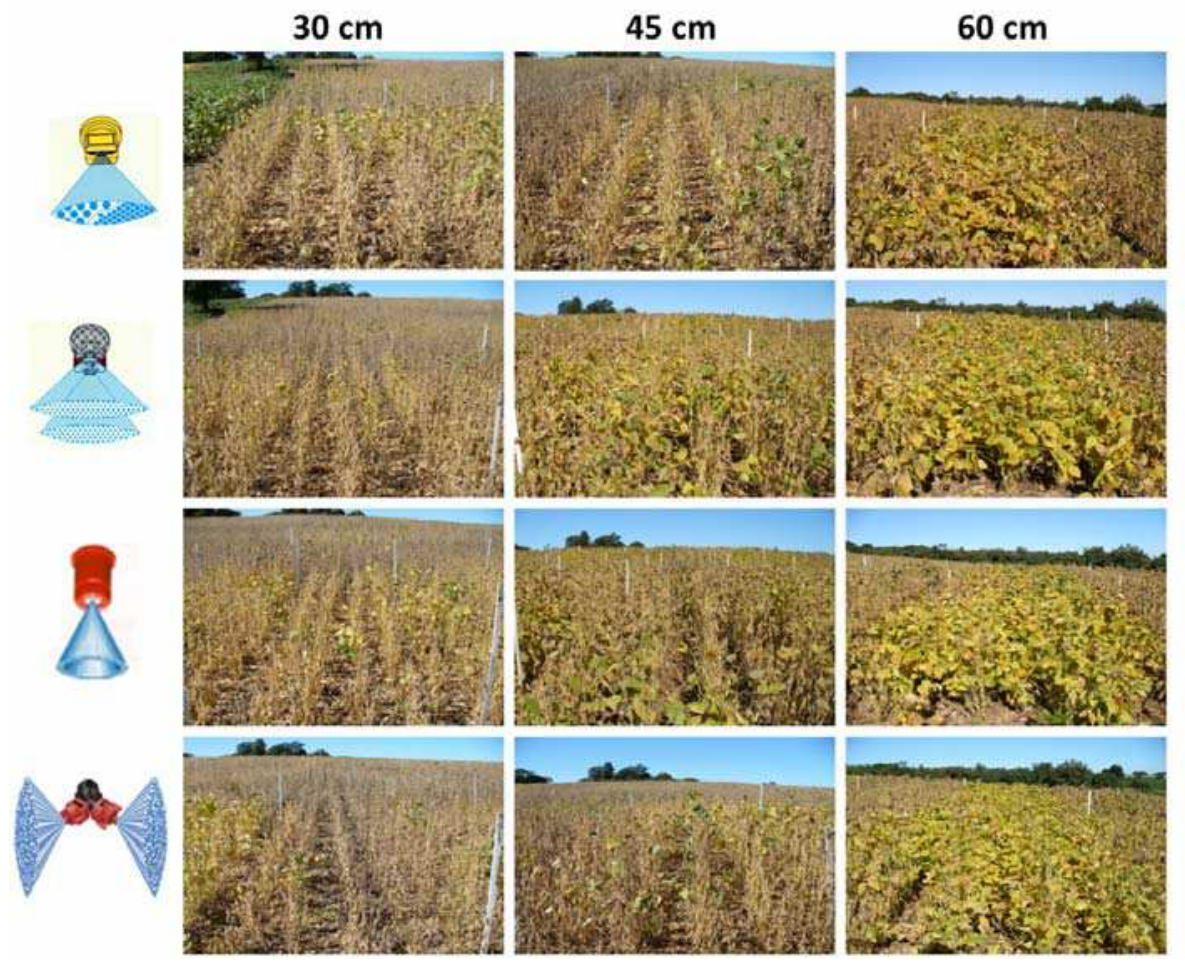

Fig. 3. Control of Phakopsorapachyrhizi (A 8000 RG) after two applications of fungicide in three rows using four nozzles (Madalosso \& Balardin, 2007). 
Adjusting the density of plants according to the plant architecture and leaf area index maximizes the residual of the fungicide, and allows greater physiological expression of the material. An experiment carried out with seven cultivars studied the effect of density of plants on the residual period after two fungicide applications showed the relationship of plant density, architecture and disease development (Figure 4).Besides the lower density of plants corresponding to a larger residual period, this condition allows the photosynthetic activity of the middle and lower will increase the yield. It was observed cultivars with high responsiveness to changes in densities opposite the positioning and pressure chemical disease and others where the variation between 16 and $30 \mathrm{pl} / \mathrm{m}^{2}$ did not showed similar result. So, residual control must be built not only focusing on the effectiveness of the fungicide, but also on the cultural management as a whole discouraging the pathogen and the emphasis on active photosynthetic area.

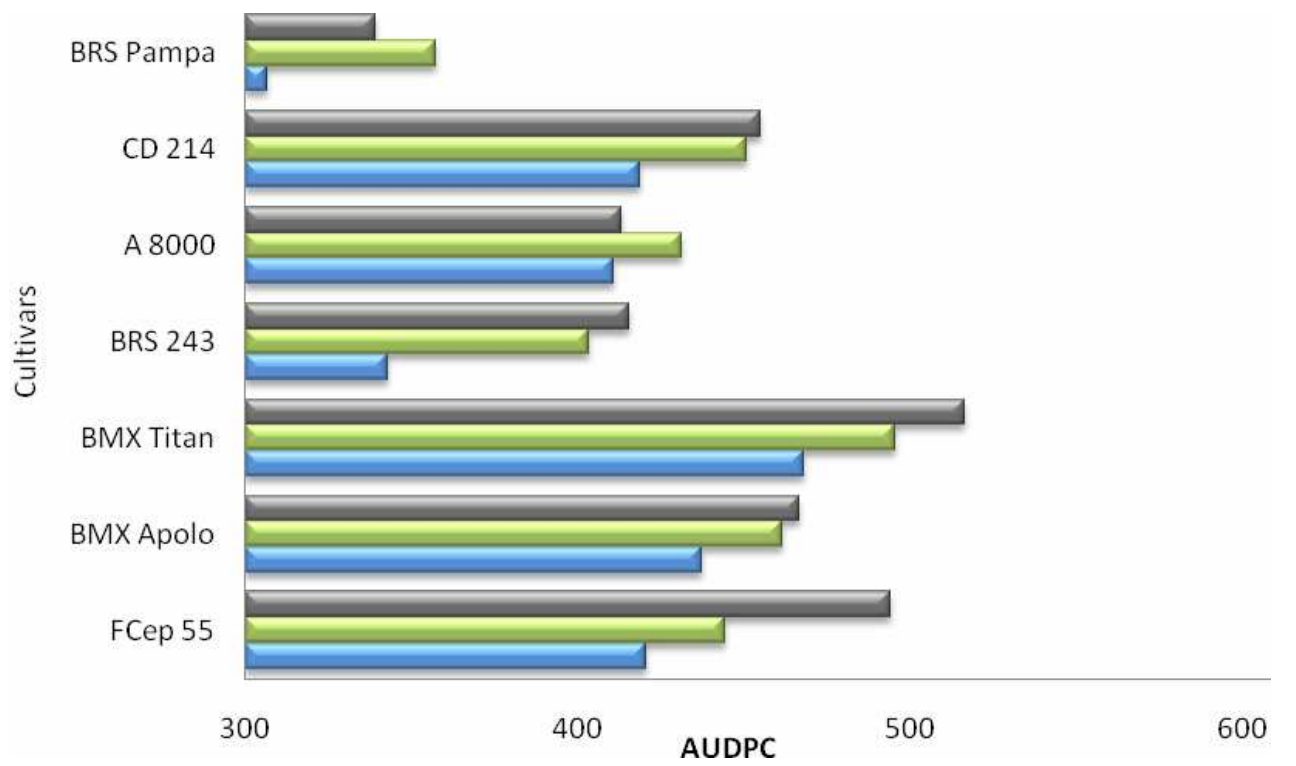

Fig. 4. Area Under Disease Progress Curve (Phakopsorapachyrhizi) evaluated on seven cultivars and three plant densities submitted two applications of fungicide. Gray $-44 \mathrm{pl} / \mathrm{ha}$; Green - 30pl/ha; Blue - 16pl/ha.

The production of soybeans is a function of canopy photosynthetic rate. This, in turn, depends on the amount of solar radiation intercepted and reaches the maximum, around 95\% interception (Rodrigues et al., 2002).

The variation of plant density changes the configuration of plant architecture through the formation of branches. In more dense cultures, the proximity of the plants reduces the capacity to issue lateral branches, while a larger distance encourages them to branch (Table 4).

Beyond the capacity of the plant emit branches, leaf area index gained importance in the analysis of product penetration (Table 3) and light inside the canopy. According to Figure 5, seven soybean cultivars responded differently as light penetration, taking into account the 
branching and leaf area. These cultivars can be grouped by their physiological plasticity as the presence or absence of response to plant density. The highest penetration of radiation are in a group of cultivars in lower densities in response to better distribution of plants, and another at higher densities, but without the issue of lateral branches (Table 4). There is also a group of cultivars that do not respond to variation in density, pointing to high leaf area as a factor that may be interfering with the deposition of fungicide compromising the residual. In this context, the reduced spacing affect the duration of residual cultivars of this group (Figure 3).

\begin{tabular}{clll}
\hline \multirow{2}{*}{ Cultivars } & \multicolumn{3}{c}{ Density } \\
\cline { 2 - 4 } & 160000 plants & 300000 plants & 440000 plants \\
\hline FCep 55 & 3,75 & 2,30 & 2,34 \\
BMX Apolo & 1,81 & 0,51 & 0,02 \\
BMX Titan & 3,92 & 3,09 & 1,71 \\
BRS 243 & 3,16 & 1,64 & 0,94 \\
A 8000 & 3,77 & 1,95 & 1,16 \\
CD 214 & 4,56 & 2,80 & 1,94 \\
BRS Pampa & 2,13 & 1,01 & 1,20 \\
\hline C.V. $\%$ & \multicolumn{2}{c}{17,23} \\
\hline
\end{tabular}

Table 4. Number of branches per plant of soybean subjected to three plant densities.Santa Maria / RS, 2010.

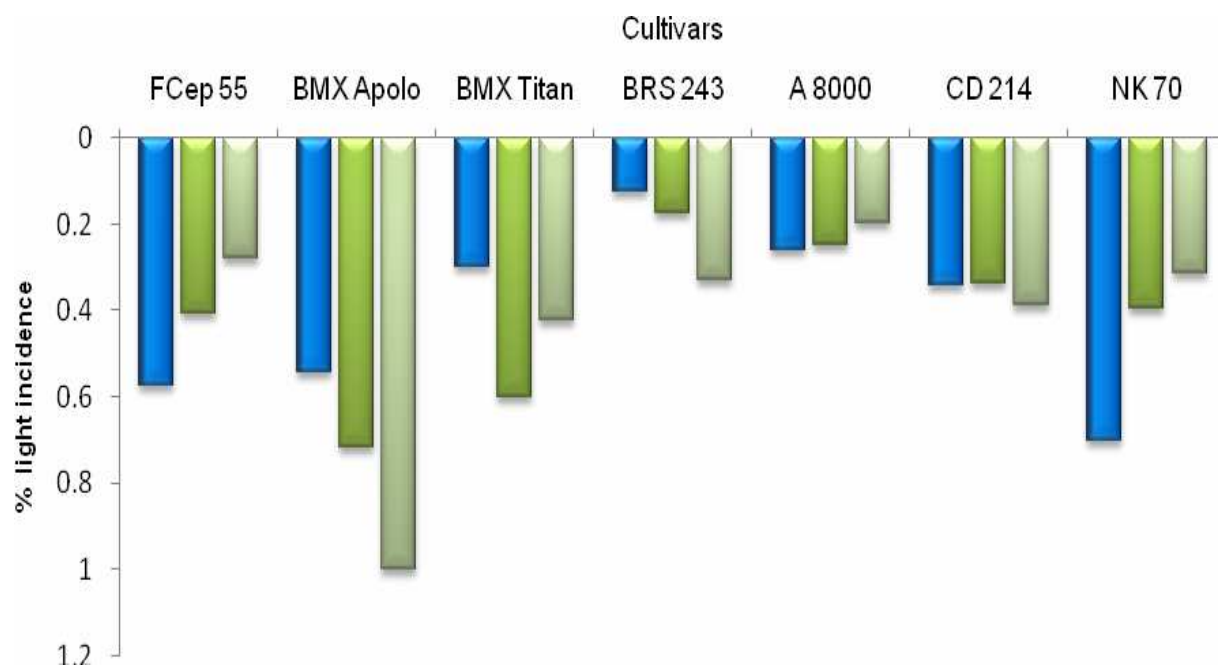

Fig. 5. Percentage of light penetration in the canopy of soybean subjected to three plant densities. Gray - 44pl/ha; Green - 30pl/ha; Blue - 16pl/ha.

The maintenance of leaf photosynthetic active in middle and bottom part of the plant canopy promotes higher number of pods in any profile of the plant (Figure 6). For Kantolic and Carmona (2006) the difference between the amount of pods is due to a deficient 
distribution of carbohydrates by reducing incident solar radiation. Besides the direct consequence on the pathogenesis, the decrease in total production of pods with the narrowing between the lines is directly related to early defoliation and shading of the lower third, resulting in a decrease in photosynthetic activity, sudden withdrawalthe setting of flowers, formation and grain filling (Taiz; Zeiger 2004; Parcianello et al., 2004).

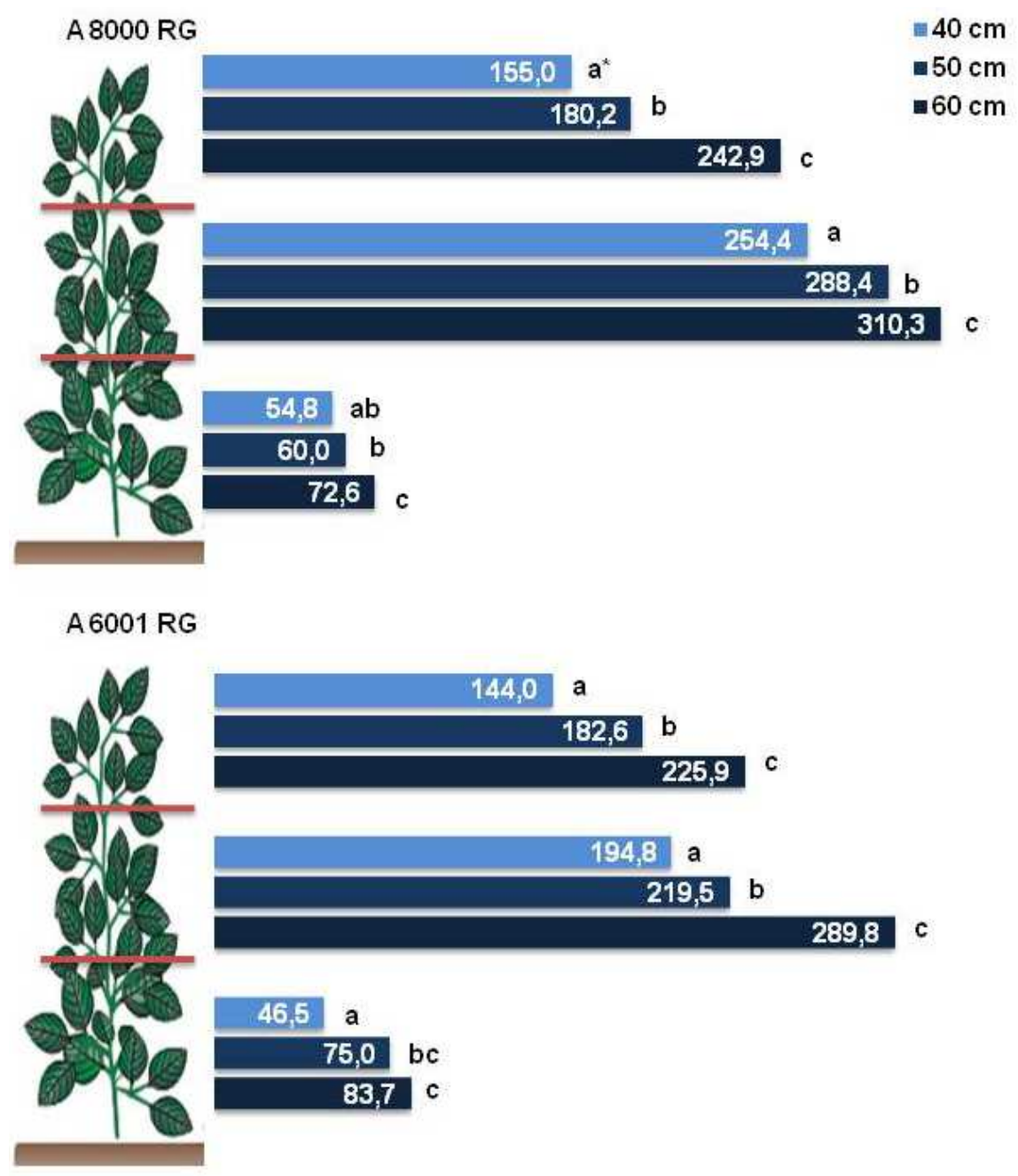

Fig. 6. Number of pods inthe cultivars A 8000 and A 6001 and three row spacing.

Taiz and Zeiger (2004) mentioned that the leaves shaded at the bottom decrease the photosynthetic activity not producing energy for absorption of nutrients. Moreover, the deficit of light allows a predisposition to attack by diseases. The greater vulnerability provided by the deficiency of radiation passes through the change in mechanical barriers 
such as plant protective waxy cuticle and stomata index (Martinset al. 1999; Vida et al., 2004).Under lower light, the cuticle tends to be thinner and also a lower deposition of waxes and may facilitate the penetration of pathogens.

Moreover, the leaves shaded at the bottom decrease photosynthetic activity, reducing the production of photo assimilates (sucrose) and cellular respiration, not producing energy for absorption of nutrients (Taiz \& Zeiger, 2004).The velocity of aging of cells is influenced by the reduction in the incidence of light triggering a cascade of physiological processes that will culminate in leaf abscission. One of these components is the phytochrome polypeptide responsible for the perception of light. Basically has two forms, a more stable and inactive form and the other more volatile and active, so the phytochrome may act as "biological switches", activating and deactivating reactions. With the shading of the leaf tissue there is a reduction of the perception of effective radiation, causing the inactivation of phytochrome. The high concentration of inactive phytochrome promotes the expression of genes that lead to the redistribution of hormones such as cytokinin, auxin and abscisic acid synthesis; there was an increase in ethylene concentration sensitizing the abscission layer.

From this new arrangement hormone, the cells of this layer become morphologically and biochemically differentiated by synthesizing and secreting enzymes into vesicles by the Golgi apparatus that will degrade these cells (Taiz \& Zeiger, 2004). Thus, there is a disruption of the cells of leaf insertion, been dropped by the wind or by its own weight (Floss, 2004).From the standpoint of production, the earlier the defoliation occurs the smaller the grain size and, consequently, the greater the damage on yields and grain quality (Yorinori, 2004).Thus, understanding the system (pathogenesis, technology application and plant physiology) in addition to the fungicide itself, determines a sum of strategies that maximize the residual control and culminate in increased revenue, strengthening the concept of integrated management of diseases.

\section{Rate of absorption}

In contrast to fungicide application, the residual period may be negatively influenced by several chemical factors, physical and biological removal or degradation of the active ingredient in the tissues of plants. The absorption rate of fungicides is dependent on several factors among which may be cited the active ingredient, formulation, chemical group, number of droplets $\mathrm{cm}^{-2}$ obtained by spraying, biological target, cultivars, age of tissues and interval between application and rainfall. Among all cases the rain has the greatest effect on residual activity and efficacy of products for foliar application. The occurrence of rain may affect the structure and activity of the product by dilution, redistribution, or physical removal by the removal of tissues.

Rain is considered the biggest detractor of fungicide deposits on the leaf surface and in this context, several factors affect the relationship between rain / residual control of fungicides, the most important being the intensity ( $\mathrm{mm} \mathrm{/} \mathrm{hour),} \mathrm{quantity,} \mathrm{time} \mathrm{interval}$ between treatment and rain, the formulation of commercial products, the solubility product in water and the culture in question. Knowledge of the persistence of the products in the tissues after the occurrence of rainfall is essential to optimize use of them. This fact allows us to estimate more precisely their residual activity and helps to establish parameters to define the need for reapplication after rain events. 


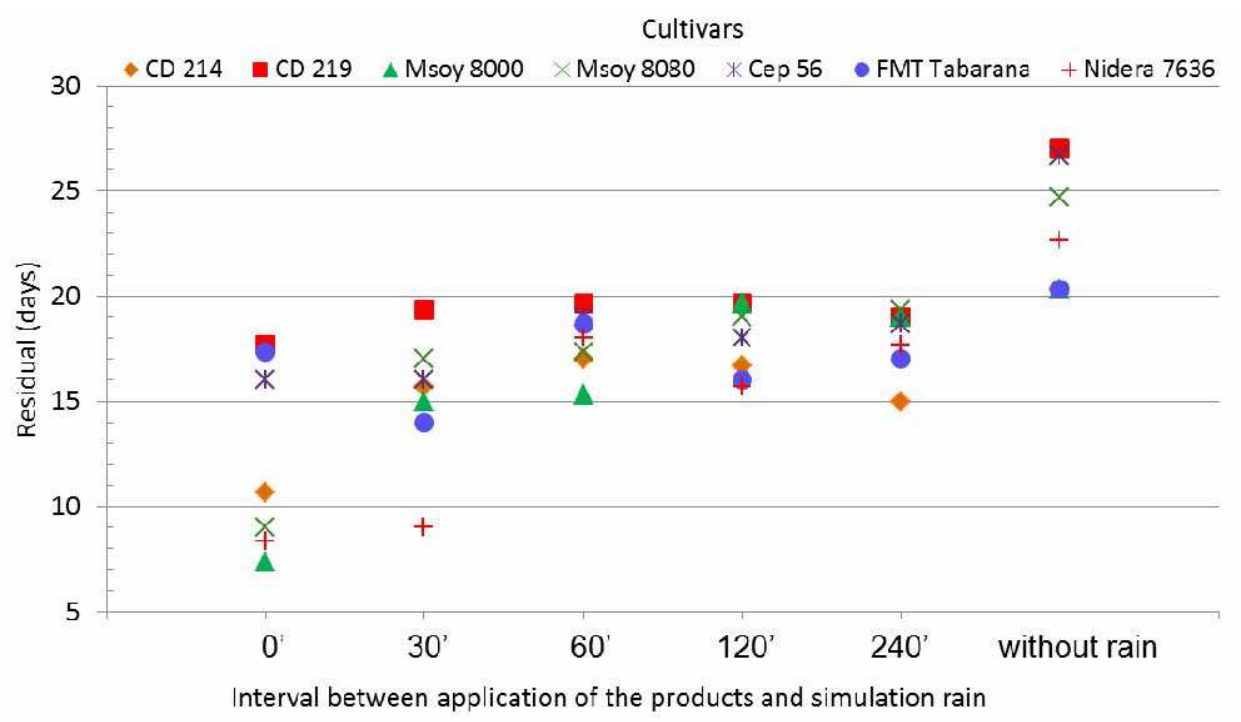

(A)

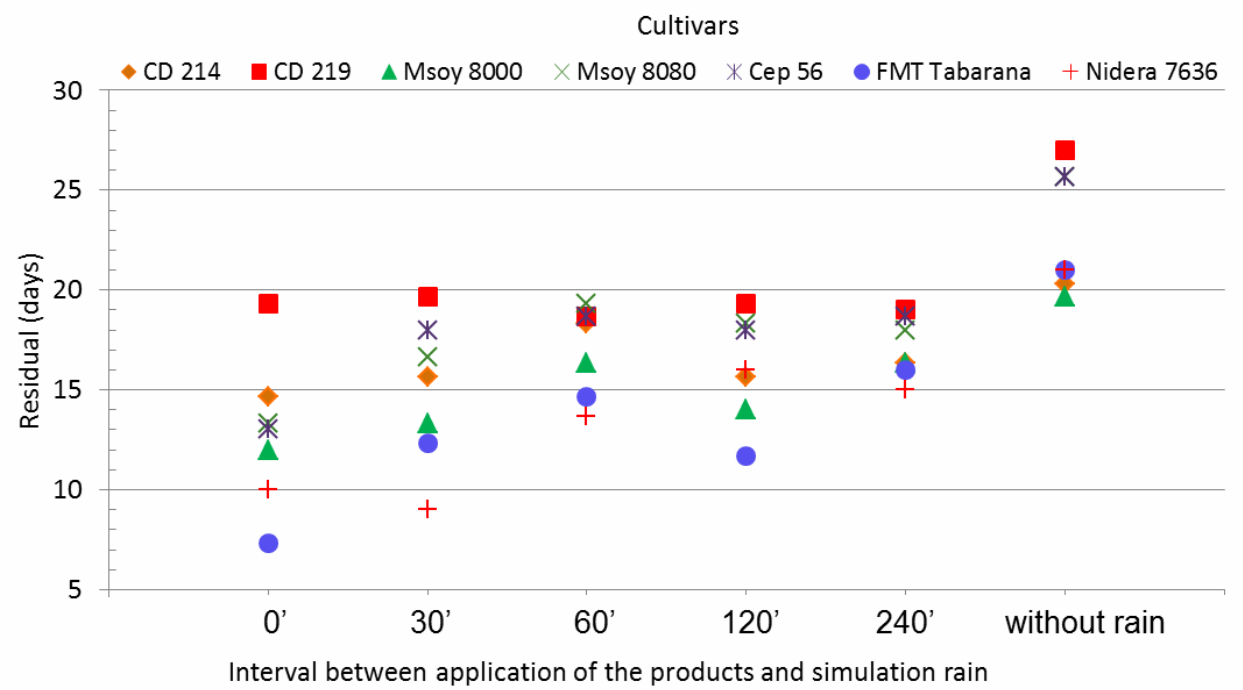

(B)

Fig. 7. Residual Control Phakopsorapachyrhizi in seven soybean cultivars.

(A) Azoxystrobin + Cyproconazole+ Nimbus; (B)Pyraclostrobin + Epoxiconazole + Assist. 
The control of Phakopsorapachyrhizi in seven soybean cultivars was studied through the application of Azoxystrobin + Cyproconazole + Nimbus (A) and Pyraclostrobin + Epoxiconazole + Assist (B), both submitted at intervals of 0', 30', 60', 120 'and 240' between the application of the fungicides and a simulated rain (Figure 7). One can see that the residual varies so much depending on the time between application and rainfall simulation as a function of cultivars and fungicides. A reduction of residual period between 7 to 10 days was observed if the simulated rain occurs 2 hours after the spray. Fungicide spray on soybean varieties has showed a difference up to 5 days.

Formulation and adjuvant also influence the rate of absorption of systemic fungicides. In general, fungicides formulated in emulsifiable concentrates more easily transposed to the cuticle layer of tissues, just as adjuvants to more easily dissolve wax layer of the epidermis. The epidermis is the main barrier to penetration of fungicides. The epidermis is composed of a cuticle that coats the leaves with a layer of 0.5 to 14 microns thick, consisting of cutin, intracuticle lipids, polysaccharides, polypeptides and phenols. However, the main barrier to penetration of fungicides is lipids intracuticle.

The epidermis of leaves is not adapted to the absorption of water-soluble substances. The entry of substances in the leaves is processed more efficiently in the lower epidermis in contrast to the upper, facilitated by lower content of lipids intracuticule and greater number of stomata. Likewise, new plant tissue offers less resistance to the absorption of fungicides, since they have thinner cuticles, which will determine a barrier more easily translatable to the fungicide. In addition to this, one should also consider that new plant tissue have a more intense physiological activity.

Control of Phakopsorapachyrhizi measured on soybean trifoliate leaves of different ages were submitted to the application of mixture of triazole + strobilurin considering large, medium and fine droplet spectra (Figure 8).It is clearly shown by the analysis of each set of data, comparing the age of first trifoliate leaves, that the number of days of residual increases as you considers the newest plant tissues. This relationship is seen for all droplets sizes and that even with the use of VMD drops high and consequently, a smaller number of droplets $\mathrm{cm}^{-2}$, new plant tissue has higher fungicide absorption. Biological efficiency of mplementation depends on the quality of coverage and penetration and reduces losses by drift and evaporation provided by the droplet diameter.

The droplet size affects the coverage, penetration and deposition thus small droplets provide better coverage, however, they may suffer more easily drift or evaporation and large drops can present problems due to the tendency of flowing and few droplets $\mathrm{cm}^{-2}$ with consequent reduced contact between product and plant. In determining the target to be reached, the product must exercise its action on the pathogen that wants to control. The goal of fungicide application is to produce a droplet size that allows good balance of coverage, penetration and droplet deposition. An implementation is one that, when performed correctly, it provides sufficient coverage of the target and it deposits the amount of defense needed to eliminate or slow down safely, a particular problem, so that economic damage is avoided.

Whenever a droplet spectrum is used and provides a greater number of droplets.cm ${ }^{2} \mathrm{a}$ greater coverage of the leaf area is observed and higher absorption and higher rate, which results in greatly increased number of days remaining. Although the younger tissues show higher rates of absorption even with the use of large drops, the greater the difference in increase of residual as they use less drops of NMD. 


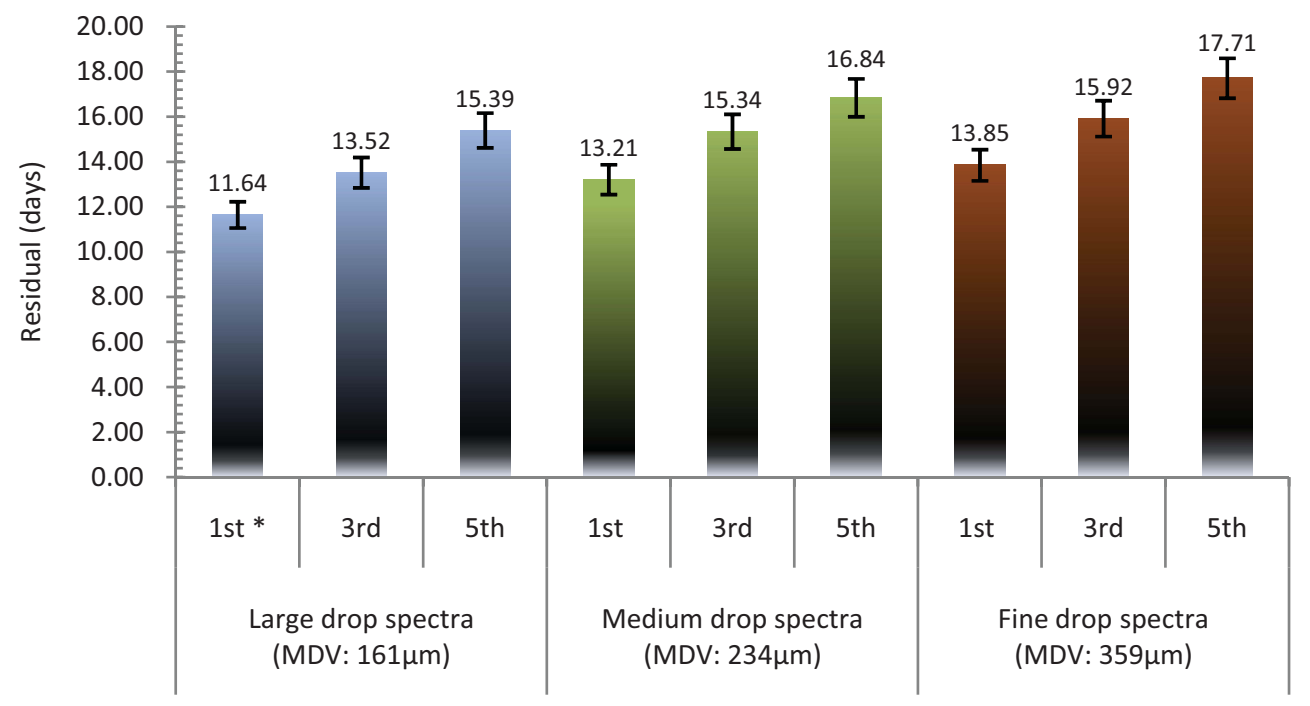

Fig. 8. Residual period to control Phakopsorapachyrhizi in trifoliate leaves of different ages undergoing spectra drops large, medium and fine. Santa Maria, 2010.

* 1st: first leaflet; 3 rd: third leaflet; 5 th: fifth leaflet. The first leaflet represent the oldest.

\section{Concluding remarks}

The effectiveness of fungicidal spray must be measured considering the gap between absolute and residual period. The combination between intrinsic characteristics of the fungicide and the established strategies of control as the moment of fungicide spray, host and pathogen population density, general characteristics of the plant as age, nutrition cultural crop practices, and the genetics expression of the resistance in the plant are among the main factors regulating the result of the fungicide spray on crops in tropical environment.

\section{References}

ANDRADE PJM, ANDRADE DFAA (2002) Rust: a threat to soybean in Brazil. Technical Circular No.11.11p.

ASAE S-572 Spray Tip Classification by Droplet Size.

www.hypropumps.com. Accessed August 1, 2010.

AZEVEDO Fungicides: basis for rational use. São Paulo, 319 p. 2003.

BALARDIN RS (2005) Notebook teaching the discipline of plant pathology farm Universidade Federal de Santa Maria - RS, Brazil, Santa Maria, Available at http://www.balardin.com.br. Accessed July 22, 2010.

CHRISTOFOLETTI, J. C. Manual Shell Agricultural Machinery and Techniques for Application of Pesticides. São Paulo, 1992. 122 p 
ELMORE, R. Crop Watch - News Service. University of Nebraska Institute of Agriculture and Natural Resources Cooperative Extension. http://cropwatch.unl.edu/archives/2004/crop04-5.htm. Accessed July 10, 2010.

EMBRAPA. Indications Techniques for Soybean in Rio Grande do Sul and Santa Catarina 2006/2007. Pelotas: Embrapa Clima Temperado, 2006.

FLOSS, E. L. Physiology of Cultivated Plants: the study who is behind what is seen. Passo Fundo: UPF, 2004. 528 p.

LEE, C D. et al. Glyphosate-Resistant Soybean Management System Effect on Sclerotinia Stem Rot. BIOONE Online Journals Access Control, 2003. Available at: http:/ / www.bioone.org/ perlserv/?request=get-document\&issn=0890037X\&volume $=019 \&$ issue $=03 \&$ page $=0580 \#$ N1. Accessed August 8, 2010.

KANTOLIC, A. G.; CARMONA, M. Bases Fisológicas de laGeneración de Rendimento: Relación com elEfecto de lãs Enfermedades Foliares y el Uso de Fungicidas em el Cultivo de Soja. 1. ed. Buenos Aires, 2006.

MADALOSSO M. G. et al.: Technology Application \& Cultural Management: Binomial Production. UFSM. Santa Maria, 2006. (Technical Information. 24).

MADALOSSO M. G. (2007) Rowspacingand spray nozzle in the Phakopsorapachyrhizi Sidowcontrol. Master Dissertation - Graduate Program in Agricultural Engineer. Federal University of Santa Maria, RS, Brazil.

MARTINS, S. R. et al. Climatic characterization and management of protected areas: the Brazilian experience. AgriculturalReport, Belo Horizonte, v. 20, n.196, p. 15-23, jan./fev. 1999.

MATUO, T. et al. Application technologyandequipment. Brasília, ABEAS; Viçosa, UFV; 2005. (Plant Protection Course. Module2 - 2.1;2.2, 86p)

OZEKI, Y.; KUNZ, R. P. Aerial Application Technology - Practical Aspects. In: GUEDES, J. V. C. \& DORNELLES S.H. B. Technology and Security in Application of Pesticides: New Technologies. UFSM, Santa Maria. 1998. p 65-78.

PARCIANELLO, G. et al. Soybean tolerance to defoliation affected by the reduction of spacing between rows. Ciência Rural, Santa Maria, v. 34, n. 2, p. 357-364, mar./abr. 2004.

RODRIGUES, O. et al. Reduced spacing in late sowing soybean. Embrapa Trigo, October, 2002, Passo Fundo, RS. (Online Documents, n. 12)

http://www.cnpt.embrapa.br/biblio/p_do12_22.htm\#endereco. Accessed July 28, 2010.

SOARES RM, RUBIN SAL, WIELEWICKI AP (2004) Asian soybean rust: history, identification and control. Fundação Estadual de Pesquisa Agropecuária FEPAGRO- Circular Técnica, nº 25, Porto Alegre, RS, 21p.

TAIZ, L.; ZEIGER, E. Plant Physiology. 3. ed. Porto Alegre: Artmed, 2004, 719 p.

UGALDE MG (2005). Asian rust control (Phakopsorapachyrhizi Sidow) In the soybean. Master Dissertation - Graduate Program in Agronomy. Federal Universityof Santa Maria, RS, Brazil.

VIDA, J. B.; et. al. Management of plant diseases in greenhouse.Fitopatologia brasileira. [online]. Brasília, v. 29, n. 4, p. 355-372, jul./ago. 2004. 
YORINORI, J. T., et al. Evolution of soybean rust (Phakopsorapachyrhizi) no Brazil, de 2001 a 2003. In: CONGRESSO BRASILEIRO DE FITOPATOLOGIA, 36., 2003, Uberlândia. Suplement. 2003. 


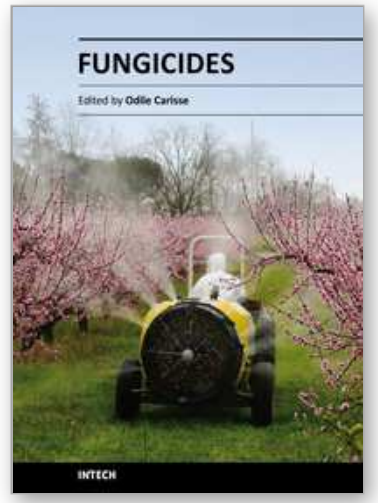

\author{
Fungicides \\ Edited by Odile Carisse
}

ISBN 978-953-307-266-1

Hard cover, 538 pages

Publisher InTech

Published online 14, December, 2010

Published in print edition December, 2010

Plant and plant products are affected by a large number of plant pathogens among which fungal pathogens. These diseases play a major role in the current deficit of food supply worldwide. Various control strategies were developed to reduce the negative effects of diseases on food, fiber, and forest crops products. For the past fifty years fungicides have played a major role in the increased productivity of several crops in most parts of the world. Although fungicide treatments are a key component of disease management, the emergence of resistance, their introduction into the environment and their toxic effect on human, animal, non-target microorganisms and beneficial organisms has become an important factor in limiting the durability of fungicide effectiveness and usefulness. This book contains 25 chapters on various aspects of fungicide science from efficacy to resistance, toxicology and development of new fungicides that provides a comprehensive and authoritative account for the role of fungicides in modern agriculture.

\title{
How to reference
}

In order to correctly reference this scholarly work, feel free to copy and paste the following:

Ricardo Balardin (2010). Factors Affecting Fungicide Efficacy in the Tropics, Fungicides, Odile Carisse (Ed.), ISBN: 978-953-307-266-1, InTech, Available from: http://www.intechopen.com/books/fungicides/factorsaffecting-fungicide-efficacy-in-the-tropics

\section{INTECH}

open science | open minds

\author{
InTech Europe \\ University Campus STeP Ri \\ Slavka Krautzeka 83/A \\ 51000 Rijeka, Croatia \\ Phone: +385 (51) 770447 \\ Fax: +385 (51) 686166 \\ www.intechopen.com
}

\author{
InTech China \\ Unit 405, Office Block, Hotel Equatorial Shanghai \\ No.65, Yan An Road (West), Shanghai, 200040, China \\ 中国上海市延安西路65号上海国际贵都大饭店办公楼405单元 \\ Phone: +86-21-62489820 \\ Fax: +86-21-62489821
}


(C) 2010 The Author(s). Licensee IntechOpen. This chapter is distributed under the terms of the Creative Commons Attribution-NonCommercialShareAlike-3.0 License, which permits use, distribution and reproduction for non-commercial purposes, provided the original is properly cited and derivative works building on this content are distributed under the same license. 